\title{
Product-Marketing Innovation, Skills and Firm Productivity Growth
}

Junge, Martin; Severgnini, Battista; Sørensen, Anders

Document Version

Final published version

Publication date:

2012

License

CC BY-NC-ND

Citation for published version (APA):

Junge, M., Severgnini, B., \& Sørensen, A. (2012). Product-Marketing Innovation, Skills and Firm Productivity Growth. Department of Economics. Copenhagen Business School. Working Paper / Department of Economics.

Copenhagen Business School No. 1-2012

Link to publication in CBS Research Portal

\section{General rights}

Copyright and moral rights for the publications made accessible in the public portal are retained by the authors and/or other copyright owners and it is a condition of accessing publications that users recognise and abide by the legal requirements associated with these rights.

\section{Take down policy}

If you believe that this document breaches copyright please contact us (research.lib@cbs.dk) providing details, and we will remove access to the work immediately and investigate your claim. 
Copenhagen

Business School

HANDELSH ØJSKOLEN

\section{Department of Economics}

Copenhagen Business School

Working paper 1-2012

\section{Product-Marketing Innovation, Skills, and Firm Productivity Growth}

Martin Junge, Battista Severgnini and Anders Sørensen

Department of Economics - Porcelænshaven 16A, 1. DK-2000 Frederiksberg 


\title{
Product-Marketing Innovation, Skills, and Firm Productivity Growth*
}

\author{
Martin Junge \\ Battista Severgnini \\ Anders Sørensen
}

July 4, 2012

\begin{abstract}
The role of product and marketing innovation for productivity growth is addressed using survey and register data for the Danish economy. It is argued that marketing and product innovation are complementary inputs and that innovation activities are skill-intensive. It is found that product and marketing innovation in skill-intensive firms results in significantly faster productivity growth than in unskilled-intensive firms that introduce this combination of innovation activities. More precisely, an increase in the share of educated workers of one percentage point, increases productivity growth by around 0.1 percentage point in firms with product and marketing innovation. In addition, it is found that firms that engage in product innovation but not in marketing innovation or the other way around do not demonstrate a growth effect from their innovation activities. It is also found that product and marketing innovation has an independent role in productivity growth that cannot be attributed to organisational changes, even though the majority of innovative firms engage in this latter innovation type.
\end{abstract}

Keywords: Product innovation, marketing innovation, organizational innovation, productivity growth, educational composition.

JEL codes: J24, O31, M31

\footnotetext{
${ }^{*}$ Battista Severgnini gratefully acknowledges financial support of the Danish Social Science Research Council-Ministry of Science, Technology and Innovation. Martin Junge. Danish Business Research Academy, Copenhagen, Denmark. Email: mj@dea.nu. Battista Severgnini. Department of Economics, Copenhagen Business School, Denmark. Email: bs.eco@cbs.dk. Anders Sørensen (corresponding author), Department of Economics, Copenhagen Business School, and Centre for Economic and Business Research, Porcelænshaven 16A, 1st floor, 2000 Frederiksberg, Denmark. Email: as.eco@cbs.dk
} 


\section{Introduction}

This paper studies effects of marketing innovation on productivity growth. We do not claim that marketing innovation necessarily play an independent role in productivity growth; rather, we hypothesise that the complementarity between product innovation and marketing innovation is an important growth driver. The motivation for this hypothesis is that the ability to come up with new and improved products and the ability to commercialise these products into demand seem to require coordination between the two activities. Empirical support for product and marketing innovation to play an independent role in productivity growth is established. More precisely, the combination of the the two innovation activities result in significantly faster productivity growth in skill-intensive firms.

Marketing innovations involve the implementation of new marketing practices. Specifically, these include changes in sales and distribution methods, changes in product design and packaging, and methods for pricing goods and services. This concept of marketing innovation follows the definition in the Oslo Manual, OECD (2005); a concept applied in the Community Innovation Survey (CIS) from which the innovation data used in this paper stem. ${ }^{1}$

During the past decade, the recognition that non-technological growth drivers are important for productivity growth has emerged. One prominent driver is organisational change. Caroli and Van Reenen (2001) argue that such changes have an independent role in productivity growth. Moreover, the authors find that organisational changes are skill-intensive, which implies that the growth effect of the activity is larger in skill-intensive firm than in unskilled-intensive firms. In another line of research, Bloom and Van Reenen (2007) establish that good management practices are important for firm productivity. More precisely, the authors find that firms with "better" management practices tend to be more productive than firms with "worse" practices and that management practices vary tremendously across firms, which suggests that large improvements in productivity are possible. ${ }^{2}$ For a survey on the empirics of organisational changes see Bloom, Sadun, and Van Reenen (2010).

Complementarities between non-technological and technological growth drivers are also important for firm performance. The relationship between organisational changes and new technologies has been shown to be important for productivity in micro studies, see for example Brynjolfsson

\footnotetext{
${ }^{1}$ In the applied version of the Danish CIS, CIS 4, no questions have been asked related to new methods of pricing goods and services. Questions related to this aspect have been introduced in later versions of the survey.

${ }^{2}$ Growth drivers related to technological development are also important; see Hall et al (2010) on the return to R\&D and Hall (2011) on product and process innovation and productivity. The latter paper finds that there are substantial positive impacts of product innovation on productivity levels but that the impact of process innovation is more ambiguous.
} 
and Hitt (2000) for a survey. The evidence shows that a combination of investment in information technology (IT) and changes in organisations contributes to firm productivity growth. Crespi, Criscuolo and Haskel (2007) use data for the UK and find a positive effect on firm performance of the interaction between IT investment and organizational innovation. Moreover, Bloom, Sadun, and Van Reenen (2012) find that the IT-related productivity advantage in the US is mainly related to "tougher" human resource management in US-owned firms compared to European owned firms.

The contribution of this paper to the literature is to investigate another complementarity between non-technological and technological growth drivers; namely, the complementarity between marketing innovation and product innovation. The importance of marketing - a non-technological growth driver - has rarely been studied in relation to firm performance. ${ }^{3}$ In the marketing literature, the idea that the success of new and better products is related to marketing activities is suggested by Gupta, Raj, and Wilemon (1986). It is argued that the success of research and development $(\mathrm{R} \& \mathrm{D})$ is potentially influenced by $\mathrm{R} \& \mathrm{D}$-marketing integration. In an empirical study, Dutta, Narasimhan, and Rajiv (1999) find that the interaction between marketing and R\&D capabilities is correlated with firm performance. The study examines a cross-section of firms and focuses on the US semiconductor industry. Moreover, Park (2004) finds in a case study that the succes of the VHS format for the videocassette recorder market at the expense of Betamax is partly explained by marketing ability.

It is important to understand the distinguishing factors between product and marketing innovation when studying the complementarity between the two innovation activities. The Oslo manual states that "the main distinguishing factor for product and marketing innovations is a significant change in the product's functions or uses." As an example, product innovation takes place when functional or user characteristics of existing products are significantly improved. Marketing innovation takes place when the design of an existing product changes significantly but this is not product innovation, as long as the functional or user characteristics are not changed significantly. ${ }^{4}$

In the present study, we formulate and test two hypotheses. Motivated by the above-mentioned studies of the integration of $R \& D$ and marketing, we formulate a hypothesis regarding the complementarity between product and marketing innovation. In relation to this, we must emphasise

\footnotetext{
${ }^{3}$ In the economic literature, marketing has sometimes been studied in relation to international trade. For example, Molina and Muendler (2010) find that firms hiring workers from marketing-related occupations at former exporters predicts a wider reach of destinations for the export decision.

${ }^{4}$ For services, "the main distinguishing factor for service innovations and marketing innovations is whether the innovation involves a marketing method or a service (i.e. a product). The distinction may depend on the nature of the firm's business."
} 
that product innovation has a much broader definition than $R \& D$ and that we do not restrict the analysis to a narrowly defined industry. The first hypothesis states that activities in product and marketing innovation have a positive effect on productivity growth and that the effect is larger than for activities in either product og marketing innovation. The motivation for this hypothesis is that product innovation generates new and improved products that potentially shift the demand curve of the firms outwards. However, to effectively approach existing or new markets with new or improved products, the firms will use marketing tools. In this respect, firms may indeed use marketing innovation to approach and reach their markets. In sum, marketing innovation is expected to be an important activity for product innovation to generate growth effects. The second hypothesis states that innovation is a skill-intensive activity.

Combining the two hypotheses, we study whether the introduction of product and marketing innovation in skill-intensive firms results in significantly faster productivity growth than in unskilled-intensive firms that introduce these types of innovation. This joint hypothesis cannot be rejected, since an increase in the share of educated workers of one percentage point, significantly increases productivity growth by around 0.1 percentage points in firms with product and marketing innovation. In addition, we find that firms that engage in product innovation but not marketing innovation or firms that engage in marketing innovation but not product innovation do not show a positive growth effect from these innovation activities.

Although the majority of innovative firms also engage in organisational innovation, we are able to rule out the concern that the estimated effect of product and marketing innovation is driven by organisational changes. More precisely, we find that product-marketing innovation as well as organisational innovation play independent roles for productivity growth. These results are obtained using two approaches. Under the first approach, we disentangle the growth effects for different innovation types. Due to multicollinearity problems, it is not possible to disentangle the separate effects of product and marketing innovation. As a result, we turn to an alternative approach under which we estimate growth effects for different firm types categorised after their innovation activities.

As a final remark, studies on innovation and firm productivity usually relate product innovation to productivity levels; see Hall (2011). Thus, the studies mainly apply cross-sectional data, and the results are of a long-run nature and do not analyse any dynamic responses. The present study focuses on productivity growth - not productivity levels - and thereby focuses on the dynamic effects of product innovation. ${ }^{5}$

\footnotetext{
${ }^{5}$ Mairesse and Mohnen (2010) survey research based on Community Innovation Surveys. In their survey they
} 
The paper proceeds as follows. The next section proposes a simple model of production and demand used to analyse innovation and firm performance. Section 3 describes the data and definitions used. Section 4 presents the empirical results. Section 5 concludes the paper. The relationship between the two approaches used in the empirical section are discussed in an appendix.

\section{Model}

\subsection{Production and demand}

The model we have in mind follows the model presented in, e.g., Hall (2011). It consists of the following components: knowledge production functions, a production function and a demand function.

Firms undertake innovation activities in order to gain a monopolistic advantage or a more effective production process. For simplicity, we assume that firms face a constant elasticity demand function of the following form:

$$
\ln Q=\eta_{0} \ln \pi+\eta_{1} \ln A^{D}
$$

with $\eta_{0}<0$ and $\eta_{1}>0 . Q$ denotes the demanded quantity, $\pi$ denotes the (relative) output price of the firm, and $A^{D}$ denotes the knowledge capital stock that is relevant for demand. $A^{D}$ constitutes a measure of the monopolistic advantage of the firm. Moreover, firms produce according to the following production function:

$$
\ln Q=\alpha_{0}+\alpha_{1} \ln K+\alpha_{2} \ln L+\alpha_{3} \ln A^{S}
$$

where $K$ denotes the physical capital stock, $L$ denotes employment, and $A^{S}$ denotes the knowledge capital stock relevant for production; a measure of the effectiveness of production.

Combining the demand and the production function results in the following function for real

refer to studies that investigate complementarities between innovation types based on cross-sectional data. Some studies focus on complementarities between product and process innovation, process and organizational innovation, and product and organizational innovation. Junge, Severgnini, and Sørensen (2012) study the long-run nature of the impact of innovation types on productivity levels using a two stage model. In this paper, evidence for complementarities between product and marketing innovation as well as between process and organizational innovation is established. 
value added:

$$
\begin{aligned}
\ln Y & =\ln \pi+\ln Q \\
& =\frac{\eta_{0}+1}{\eta_{0}}\left(\alpha_{0}+\alpha_{1} \ln K+\alpha_{2} \ln L\right)+\frac{\alpha_{3}\left(\eta_{0}+1\right)}{\eta_{0}} \ln A^{S}-\frac{\eta_{1}}{\eta_{0}} \ln A^{D}
\end{aligned}
$$

where $Y$ denotes real value added. In the next sub-section, we turn to the knowledge function of the model.

\subsection{Knowledge Creation}

Firms can conduct product innovation and/or marketing innovation. In addition to these innovation types, firms can also engage in organisational innovation. We include the latter innovation type because it is an important growth driver, as discussed in the introduction, and because the majority of firms that conduct product innovation also conduct organisational innovation, as descriped below. The three innovation types are denoted by $P$ (product innovation), $M$ (marketing innovation), and $O$ (organisational innovation), respectively. ${ }^{6}$ Innovation activities potentially affect real value added through the growth rate of knowledge capital, i.e., $\Delta \ln A^{S}$ and $\Delta \ln A^{D}$. We assume that knowledge production relevant for demand, $A^{D}$, is affected through product innovation and marketing innovation, whereas organizational innovation is important for the knowledge production relevant for the production function, $A^{S}$.

An important element that we study is the complementarity between product and marketing innovation in the knowledge creation of $A^{D}$. We hypothesise that marketing innovation strengthens the growth effect of product innovation (and the other way around). In other words, firms that expend the effort to bring their products to market by developing sales and distributions methods or by changing the design or packaging in addition to innovating new and improved products are expected to perform better than firms that do not. Another important aspect is that innovation is assumed to be a skill-intensive activity. The introduction of innovation activities in skill-intensive firms is expected to lead to significantly faster productivity growth than the introduction of innovation activities in unskilled-intensive firms.

The innovation process generates new knowledge and the development is assumed to follow the

\footnotetext{
${ }^{6}$ Firms can also perform process innovation. This innovation type is not included in the analysis because it is out of the scope for the analysis. Even if this type was included no empirical importance is found. The results are available upon request.
} 
equations

$$
\begin{aligned}
\Delta \ln A^{D} & =f\left(I^{P}, I^{M}\right) E \\
\Delta \ln A^{S} & =I^{O} E
\end{aligned}
$$

where $I^{P}, I^{M}$, and $I^{O}$ denote intensities of product, marketing and organizational innovation, respectively. $E$ denotes the education mix, where high values indicate skill-intensive firms and low values indicate unskilled-intensive firms. Therefore, a key explanatory variables in the knowledge production function is the education mix of the firms. We do not target specific departments of firms when focusing on the relationship between the education mix and knowledge production (i.e., we do not restrict the analysis to employees in $R \& D$ or other specific departments of firms). Rather, we assume that a more intensive overall use of educated workers increases the intensity of the different innovation types and that these activities can be performed in any part of a firm. ${ }^{7}$

Furthermore, it is assumed that product and marketing innovation are complementary, which implies that:

$$
\left(\frac{\partial f\left(I^{P}, I^{M}\right)}{\partial I^{M}}\right) / \partial I^{P}=\left(\frac{\partial f\left(I^{P}, I^{M}\right)}{\partial I^{P}}\right) / \partial I^{M}=\frac{\partial^{2} f\left(I^{P}, I^{M}\right)}{\partial I^{P} \partial I^{M}}>0
$$

The effect of more intensive product innovation activities increases the effect of marketing innovation on knowledge creation (and the other way around).

Moreover, the assumption of innovation as a skill-intensive activity implies that

$$
\frac{\partial^{2} \Delta \ln A^{D}}{\partial I^{P} \partial E}>0, \frac{\partial^{2} \Delta \ln A^{D}}{\partial I^{M} \partial E}>0, \frac{\partial^{2} \Delta \ln A^{S}}{\partial I^{O} \partial E}=1>0
$$

\footnotetext{
${ }^{7}$ Variation in marketing capabilities across firms may also be important for the growth effect of production innovation, in the sense that a high marketing capability may lead to a larger growth effect than for low marketing capability. We do not study this aspect because we do not have data on marketing capabilities.
} 


\subsection{Real Value Added Growth}

Using (1) and (2), we derive the growth rate of real value added as a function of innovation activities:

$$
\begin{aligned}
\Delta \ln Y= & \frac{\eta_{0}+1}{\eta_{0}}\left(\Delta a_{t}+\alpha_{1} \Delta \ln K+\alpha_{2} \Delta \ln L\right) \\
& +\frac{\alpha_{3}\left(\eta_{0}+1\right)}{\eta_{0}} I^{O} E-\frac{\eta_{1}}{\eta_{0}}\left(\phi_{1} I^{P}+\phi_{2} I^{M}+\phi_{3} I^{P} I^{M}\right) E+\varepsilon
\end{aligned}
$$

where we treat $\alpha_{0}=a_{i}+a_{t}+u_{i, t}$, with $\Delta u_{i, t}=\varepsilon_{i, t}$. Moreover, we model function $f($.$) as$ $f\left(I^{P}, I^{M}\right)=\phi_{1} I^{P}+\phi_{2} I^{M}+\phi_{3} I^{P} I^{M}$. In sum the model to be estimated in the empirical section below equals:

$$
\Delta \ln Y=\beta_{0}+\beta_{1} \Delta \ln K+\beta_{2} \Delta \ln L+\lambda_{1} I^{P} E+\lambda_{2} I^{M} E+\lambda_{3} I^{P} I^{M} E+\lambda_{4} I^{O} E+\varepsilon
$$

where the coefficients are determined by $\beta_{0}=\left(\eta_{0}+1\right) \Delta a_{t} / \eta_{0}, \beta_{1}=\left(\eta_{0}+1\right) \alpha_{1} / \eta_{0}$ etc. Our main interest is in the interaction term, i.e., $\lambda_{3}=-\eta_{1} \phi_{3} / \eta_{0}$. The advantage of estimating the regression in first differences is that it includes firm-specific fixed effects to control for unobserved firm heterogeneity.

\section{Data and definitions}

The applied data set stems from two sources. First, data on innovation activities originate from the Danish version of the Community Innovation Survey (CIS) from 2004 that constitutes a representative sample for the Danish economy. This data set includes information on innovation activities at the firm level. The questions on innovation activities are related to innovation activities performed in firms during the 3-year period from 2002-2004. Second, other firm variables that originate from the Danish register data sets IDA and FIDA are included. Specifically, the backbone of the analysis is an employer-employee matched data set that enables us to track educational attainment for each employee in every single firm. Consequently, it is possible to obtain very precise measures of the education mix applied in each firm. Moreover, firm information in the data set provides data on value added, labour input, and input of physical capital. In addition, we also apply industry, regional, and ownership dummies as well as export intensities. Finally, the register data allows the possibility of measuring the variables for different years. We apply and describe this possibility below. 


\subsection{Innovation}

In the empirical analysis three types of innovations are applied. The three types are product innovation $(P)$, marketing innovation $(M)$, and organisational innovation $(O)$ :

A firm is considered to perform:

- product innovation if it answers yes to the question: "Did the firm introduce new or significantly improved products or services?"

- marketing innovation if it answers yes to one or both of the questions: "Did the firm introduce (i) new or significantly changed sales or distribution methods or (ii) significant changes in a product or service design or packaging?"

- organisational innovation if it answers yes to one or both of the following questions: "Did the firm introduce (i) new or significantly improved business processes for better use or exchange of information, knowledge and skills in the firm or (ii) a major organisational change within the company?"

Unfortunately, we cannot observe innovation intensities. Based on the innovation questions, we therefore construct binary indicators from the survey data that indicate whether firms had innovation activities of the three types during 2002-2004. These binary variables are used as measures for innovation activities below.

\subsection{Other firm-specific variables}

Real value added, $Y$, is measured as value added in current prices deflated by narrow industry specific price series. Physical capital, $K$, is measured as fixed assets and stems from accounting data, whereas labour input, $L$, is measured by full time equivalent units. These variables are used to determine long log-differences between 2004 and 2007. These log differences are measured as annualised changes. As a measure of the education mix in the single firm, $E$, we take the share of full-time employees in the firm with at least 16 years of education out of total number of employees. By this measure, the higher is $E$ the more skill-intensive is a firm. The descriptive statistics of the sample are shown in Appendix Table 1. 


\section{Empirical results}

This section presents the empirical results of the study. First, we comment on a number of econometric problems that are dealt with in the analysis. Second, we present the descriptive statistics, and finally, we present the results of the regression analysis.

\subsection{Econometric Problems}

There are a number of econometric problems in estimating the relation between productivity and the knowledge stock of the firm. Specifically, these problems are unobserved heterogeneity and endogeneity. We deal with unobserved heterogeneity by estimating the model in first differences, as discussed in relation to (3) above. Consequently, we apply annualised changes during the period 2005-2007. To mitigate endogeneity, we use lagged innovation variables in the regressions, see Griffith, Redding, and Van Reenen (2004). More precisely, we use data for innovation activity for the period 2002-2004. Moreover, we apply an initial skill share; the education share measured in the first week of November 2001, i.e., the share is measured before the period that the innovation measures apply for. The timing of the dependent and explanatory variables is illustrated in Figure 1.

$<$ Figure 1 around here $>$

To deal with a potential selection problem, we include lagged growth rates in one of the regressions in the robustness section, i.e., Section 4 below. That is we include the annualized log-change in real value added over the period 2002-2004 as explanatory variable. The issue is that highgrowth firms potentially select themselves into innovation activities and low-growth firms do not. More precisely, the lagged growth rates are instrumented with the initial real value added level as measured in 2001, which follows Caroli and Van Reenen (2001).

\subsection{Descriptive Statistics}

Innovation activities for the firms in our sample are presented in Table 1. In Table 1a, the firms are grouped after whether they perform product and/or marketing innovation, whereas they are grouped after product, marketing and organisational innovation in Table 1b.

$<$ Table 1 around here $>$ 
In Table 1a, it is evident that 527 firms out of 1,321 firms - representing 40 per cent of the firms in the sample - engage in product innovation. Of these firms, approximately one third conduct marketing innovation in addition to product innovation, whereas the remaining two thirds do not conduct marketing innovation. Moreover, it is seen that 261 firms engage in marketing innovation. Of these firms, about 60 per cent also perform product innovation.

In Table $1 \mathrm{~b}$ it is seen that 401 firms out of 527 firms conducting product innovation also engage in organisational innovation; i.e., three quarters of the firms conducting product innovation also perform organisational innovation. For the group of firms engaging in both product and marketing innovation, as many as 83 per cent also conduct organisational innovation. It is also evident that 307 firms - nearly one fourth of the sample - engage in organisational innovation without conducting either marketing or product innovation. Approximately 60 per cent of the firms engage in organisational innovation, implying that the majority of the 71 per cent of firms in the sample that conduct innovation activities are conducting organisational organisation. 29 per cent of firms do not engage in innovation activities.

Before turning to the regression analysis, we present the average measures of labour productivity growth divided by innovation type and skill intensity. In Figure 2, the average growth rates of skillintensive firms are compared to the average growth rate of all firms. The growth rates are presented as deviations from the average growth rate for different firm types defined after the innovation activities that they engage in. Moreover, firms are considered to be skill-intensive if their education share in 2001 exceeds the median share within their firm type.

We split the data into four types of innovative firms according to the innovation activities that they engage in. The firms are grouped according to whether they conduct (1) product-marketing innovation $(P M),(2)$ product innovation but no marketing innovation $(P N M)$, (3) marketing innovation but not product innovation $(N P M)$, or (4) organisational innovation but no product or marketing innovation $(O N P N M)$. Finally, we also include firms without innovation activities $(N I){ }^{8}$

$<$ Figure 2 around here $>$

\footnotetext{
${ }^{8}$ We only apply 4 firm types with innovation activities in the main text to reduce the number of parameters to estimate. This is the case even though the combinations of three innovation types result in 7 firm types with innovation activities. See the appendix for a discussion.
} 
A number of interesting observations are shown in Figure 2. It is clear that skill-intensive firms with innovation activities grow faster than the average firm within the same firm types and thereby unskilled-intensive firms. This effect is found for all firm types with innovation and suggests that innovation is indeed a skill-intensive activity. It is especially pronounced for firms that engage in product and marketing innovation. A second and somewhat surprising observation is that within the group of firms without innovation activities, unskilled-intensive firms grow faster than skill-intensive firms. This observation should not be taken at face value, but rather understood as indicating that skill-intensive non-innovators do not grow faster than unskilled-intensive non-innovators. In other words, this observation suggests that growth effects of skills to a large extent work through the innovation channel, i.e., skills are contributing to knowledge creation.

There are also a number of things we cannot determine from Figure 2. We cannot determine whether the growth effects are significantly different from zero. We do not control for other background characteristics of the firm than the skill intensity. Moreover, it is not possible to contribute growth effect to the different innovation activities. Most problematic is the growth performance of product innovation and/or marketing innovation because the majority of innovative firms perform organizational innovation. This is especially outspoken for firms that perform both product and marketing innovation, which was evident from Table 1 . In this sense, we cannot determine whether it is organizational innovation, product-marketing innovation or both that drives the growth performance in firms. Consequently, we have to disentangle the effect of organisational innovation from the other types of innovation. These concerns will be taken into account in the next section.

\subsection{Regression results}

In the following two sets of regression results are presented. First, we focus on the growth effects of different innovation types. That is, we attempt to disentangle the growth effects of the three innovation types: product, marketing, and organisational innovation. From an empirical perspective, disentangling effects of the different innovation types is challenging because most of these coexist in the production function and thus create possible problems of collinearities (Anderson and Schmittlein (1984), Milgrom and Roberts (1990), and Athey and Stern (1998)). As it turns out, we are able to obtain precise estimates of the combined growth effects of product and marketing innovation as well as organisational innovation. It is, however, not possible to determine the separate effects of product innovation or marketing innovation. As a consequence we focus on firm types that are engaging in different types of innovation rather than focusing on different innovation types. More precisely, we present results for the four types of innovative firms defined in relation to Figure 2 above. The two approaches are derived from the same general model. Moreover, the 
empirical results obtained under the two approaches are qualitatively the same. These aspects are discussed in Appendix A.

\subsubsection{Innovation types}

First, we present the results for the growth effects of different combinations of product and marketing innovation in Table 2. Next, we include organisational innovation in addition to product and marketing innovation in Table $3 .^{9}$

In Table 2, the regression results of including product innovation, marketing innovation, and the interaction term of the two innovation types are presented. In the first two columns, we introduce the two innovation types one at a time. In column 1, product innovation is introduced and the relationship between growth in real value added and this innovation type is estimated. The interaction term between product innovation and the education share, i.e., the coefficient of $P \cdot E$, is positive and significantly different from zero. The point estimate for the interaction term equals 0.087 and is significantly different from zero at the 5 per cent level. This implies that skill-intensive firms that engage in product innovation grow faster than skill-intensive firms that do not engage in product innovation. More precisely, an increase in the skill intensity of one percentage point, increases productivity growth by almost 0.1 percentage points in firms with product innovation.

$<$ Table 2 around here $>$

It is also evident in column 1 that the direct coefficient to product innovation, i.e., the coefficient of $P$, is approximately zero, implying that the average firm does not obtain any growth effect for product innovation. This also means that the skill intensity may be too low to generate positive growth effects, since the demeaned effect of $P \cdot E$ is negative for firms with a skill share below average. I.e., the growth effect may actually be negative, if the skill intensity is below a threshold level. Taken at face value, firms with a skill intensity below 0.1663 will experience a negative growth effect of conducting product innovation, whereas firms with a skill intensity above 0.1663 will have positive growth effects. This difference suggests that innovation only pays off growth-wise in skill-intensive firms. This effect is also found for organisational innovation in Caroli and Van Reenen (2001).

\footnotetext{
${ }^{9}$ In the regression analysis, the interaction terms are determined as the interaction between innovation dummies and the demeaned skill-intensity. Subtracting the mean of the skill share, ensures that average treatment effect (ATE) is the coefficient on the innovation dummy itself.
} 
In column 2, marketing innovation is included as the only innovation type in the growth regression. As for product innovation, the interaction term between innovation and the skill intensity enters with a positive value; however, in this case, the value is not significantly different from zero. Column 3 presents the results of including both product and marketing innovation as separate and non-complementary activities. The findings in column 3 reflect those of columns 1 and 2 .

Column 4 includes the interaction between product and marketing innovation. It is clear that the estimates are influenced by multicollinearity problems. All three estimates for the innovation types are imprecise. The combined growth effect of conducting product and market innovation simultaneously when the two types of innovation are treated as complementary is equal to 0.131 $(=0.045-0.120+0.206)$; this value is significant at the 1 per cent level when using an F-test, which is shown in the bottom part of the column.

Because the direct effect of marketing innovation was found to be insignificant in column 2, it is excluded in column 5. By excluding this effect, we find positive but insignificant separate effects of product innovation. Moreover, the combined effect of engaging in product and marketing innovation equals $0.141(=0.059+0.086)$, which is of similar magnitude to the total effect found in column 4. Again, this effect is found to be significant at the 1 per cent level using an F-test. Finally, the direct effect of product innovation is also excluded in column 6 . In this case, we find that the coefficient for the interaction between product and marketing innovation is equal to 0.127 , which is significant at the 1 per cent level.

The results of Table 2, however, can be questioned: is the growth effect of product and marketing innovation actually captured by the estimated coefficients in the growth regressions? As was evident from Table 1, three quarters of firms with product innovation and/or marketing innovation also engage in organisational innovation. Therefore, the growth effect from organisational innovation may be picked up by the applied measures of product and marketing innovation. Another important reason to worry about the growth driving effect is articulated by Caroli and Van Reenen (2001), who study growth effects of organisational changes. This work argues that organisational change has an independent role in productivity growth. Moreover, the results demonstrate that organisational changes are skill-intensive, as was found for product-marketing innovation above.

For these reasons, we include organisational innovation in the growth regressions in addition to product and marketing innovation. The results are presented in Table 3. In column 1, organisational innovation is included as the only innovation type. It is shown that organisational innovation activities have a positive growth effect for skill-intensive firms, a result that parallels the findings 
in Caroli and Van Reenen (2001). In this sense, organisational innovation indeed has an important role to play for economic growth.

$<$ Table 3 around here $>$

In column 2, we include product and marketing innovation in addition to organisational innovation. Again, the estimation for product and marketing innovation suffers from multicollinearity due to the innovation structure, as presented in Table 1. Therefore, we evaluate the effect of conducting product-marketing innovation as the total effect of product innovation and marketing innovation. The combined effect is positive and equal to $0.099(=0.196-0.120+0.022)$, which is significant at the 10 per cent level when using an F-test. In other words, we find lower significance when including organisational innovation but the effect is still positive and significant. As in column 1, we find that organisational innovation has a positive growth effect in skill-intensive firms; however, the effect is no longer significant. This result may well be due to the fundamental multicollinearity problem.

In columns 3 and 4, the direct effects of marketing and product innovation are removed one at a time, as was the case in Table 2. In column 3, marketing innovation is removed. In this case the common effect for product and marketing innovation is equal to $0.113(=0.077+0.036)$ and is significant at the 5 percent level. When both direct effects are removed, the coefficient for the interaction term between product and marketing innovation equals 0.100 that is also significant at the 5 percent level. The coefficients for organisational innovation, $O \cdot E$, are positive in both specifications; however, the coefficient of column 3 is insignificant, whereas it is significant at the 10 percent level in column 4 .

In sum, we find that skill-intensive firms that both perform product and marketing innovation experience a positive growth effect. Since we are able to disentangle the effects of product-marketing innovation and organisational innovation, we can conclude that this effect is not driven by organisational innovation. An increase in the share of educated workers of one percentage point, increases productivity growth by around 0.1 percentage points in firms with product and marketing innovation, whereas productivity growth increases by around 0.08 percentage points in firms that perform organisational innovation. The positive growth effect may require that the skill intensity, as measured by the share of employees with 16 or more years of education, exceeds a threshold level.

As final remarks it should be mentioned that the skill-intensity itself does not contribute to growth, i.e., skills only have a growth effect through innovation. This is the case for all regressions 
reported in Tables 2 and 3 since the point estimates on the lagged skill-intensity is insignificantly different from zero in all the regressions; a result that was also evident in Figure 2 above. Moreover, the conventional factors labor and capital take their expected signs. The point estimate on growth of labor equals 0.84 , which is close to the share of labor costs in value added and it is in line with estimates found elsewhere in the literature. The point estimate on growth of capital equals 0.03. Even though it is a relatively low value this magnitude is found elsewhere, see for example Balsvik (2011). One potential explanation for the low point estimate is that capital is measured by fixed assets that origin from accounting data; a measure that does not measure physical capital as precise as we would prefer. This implies that capital has measurement errors that is likely to be exacerbated as a consequence of differencing.

Due to the low point estimate on growth of capital the hypothesis of constant returns to scale in labor and capital is rejected at the 1 per cent level when using a F-test. In spite of this inappropriate result, the main conclusions derived above and in the next section are unaffected by the inclusion of poorly measured physical capital. We conclude this because the qualitative results for the growth effects of innovation is unaffected when constant returns to scale is enforced on the regressions.

\subsubsection{Firm types}

An alternative estimation approach that deals with the multicollinearity problem of different innovation types is to estimate growth effects of different firm types. Under this alternative approach, we split the firms into the 4 types of innovative firms used in Figure 2.

The results are presented in Table 4. It is shown in column 1 that skill-intensive firms that conduct product-marketing innovation have higher growth effects of innovation than firms that conduct either product innovation or marketing innovation. Firms that engage in product innovation but not marketing innovation experience a positive growth effect, however, the effect is not significantly different from zero. Moreover, the growth effect for firms with marketing innovation but no product innovation is negative but insignificant.

$<$ Table 4 around here $>$

Again, it should be emphasised that firms belonging to one of the three firm types may also conduct organisational innovation in addition to product and/or marketing innovation. Therefore, it is difficult to determine whether the growth effect stems from product and/or marketing innovations or whether it is due to organisational innovation. Therefore, the strategy applied in the following is 
to test whether skill-intensive firms with product and/or marketing innovation have a significantly higher growth effect than firms that have organisational innovation only.

In column 2, we also include firms that engage in organisational innovation but no marketing innovation or product innovation. In this case, we establish that firms with product-marketing innovation have higher growth effect than firms with organisational innovation only. To investigate whether this difference is significantly different from zero, we perform a one-sided Wald test. The difference is found to be significant, which is clear from the F-test in the bottom part of column 2. This implies that the null hypothesis (no or a negative difference) is rejected with a p-value of 0.056. We interpret the positive difference between the two coefficients as the contribution from product-marketing innovation. This implies that an increase in the share of educated workers of one percentage point, increases productivity growth by $0.086(=0.168-0.082)$ percentage points in firms with product and marketing innovation.

Firms with product innovation but no marketing innovation and firms with organisational innovation only demonstrate growth effects from innovation of similar magnitudes. This similarity suggests that product innovation in itself does not contribute to economic growth because a large fraction of the firms conducting product innovation also conduct organisational innovation. Firms with marketing innovation but no product innovation has a negative but insignificant growth effect from innovation. Consequently, product and marketing innovation in itself do not contribute to productivity growth.

To come closer to the additional effect of product-marketing innovation over and above the effect of organisational innovation, we exclude innovative firms that do not engage in organisational innovation. This means, for example, that firms that conduct product-marketing innovation but no organisational innovation are excluded from the sample in column 3. However, firms without innovation activities are included. Using this restriction, 163 innovative firms are excluded, resulting in a sample of 1,158 firms. The results for the restricted sample imply that skill-intensive firms that engage in product, marketing, and organisational innovation have significantly higher growth effects than skill-intensive firms that conduct organisational innovation only at the 10 percent significance level. The impact on productivity growth of an increase in the skill share of one percentage point equals $0.070(=0.155-0.085)$ percentage points.

Firms with product and organisational innovation but without marketing innovation and firms with marketing and organisational innovation but without product innovation have a larger growth effect than firms with organisational innovation only. The differences are, however, not statistically 
significant implying that product innovation without marketing innovation and marketing innovation without product innovation do not contribute significantly to productivity growth. It is interesting that the point estimate to marketing innovation becomes positive when excluding firms performing marketing innovation only instead of a negative effect when included as in columns 1 and 2 .

Finally, in column 4 we only include firms that conduct organisational innovation, implying that we exclude firms with innovation activities that do not perform organisational innovation, from the sample. This exclusion results in a sample of 776 innovative firms presented in Table 1b. We find that product-marketing innovation generates higher growth effects in skill-intensive firms than in firms that conduct product innovation but not marketing innovation, marketing innovation but not product innovation or organisational innovation only. Only the interaction term for firms with product-marketing innovation is significantly different from 0 .

In summary, the conclusion drawn from Table 4 is that skill-intensive firms with productmarketing innovation experience a positive growth effect in the 3-year period after the innovation activity took place. The growth effect in skill-intensive firms engaging in product-marketing innovation significantly exceeds that of firms conducting organisational innovation only. This is an important result because many firms that conduct product-marketing innovation also conduct organisational innovation. To rule out the possibility that the growth effect for product-marketing innovation is driven by organisational innovation, the growth effect for firms performing product and marketing innovation must exceed that of firms engaging in organisational innovation only. This is exactly what we find. Moreover, we find that skill-intensive firms that engage in product and organisational innovation do not have a higher growth effect than skill-intensive firms that engage in organisational innovation only. This suggests that product innovation without marketing innovation does not contribute to productivity growth. A similar result is found for marketing innovation.

Taking the results in Tables 2-4 as a whole, the evidence is clear that product-marketing innovation and organisational innovation both generates positive growth effects and that innovation is a skill-biased activity.

\subsubsection{Robustness}

Finally, we investigate the robustness of the results established for product and marketing innovation in the section above. We present a number of alternative specifications in Table 5. In column 
1 of the table, we present our baseline specification of the previous sections, namely column 2 of Table 4 . We compare this specification against the alternative regressions. ${ }^{10}$

$<$ Table 5 around here $>$

The first issue addressed in Table 5 is firm size. The applied binary measure of product innovation may be problematic because large firms have a tendency to answer "yes" to the question of whether they engage in product innovation or not. In the words of Hall (2011), p. 176, "When examined across a range of firm sizes, it produces the misleading results that larger firms are more likely to be innovative, whereas in truth larger firms are involved in a wider range of activities and are therefore more likely to have an innovation in at least one of them."

We expect the "size" problem to be especially pronounced for product innovation. We do not expect firm size to be an important problem for marketing and organisational innovation. Marketing innovation will to a large extent be focussed on overall firm demand, whereas organisational innovations are expected to be implemented for the firm as a whole.

The results when splitting the sample by firm size are presented in columns 2 and 3. Column 2 presents firms with employment below the median level of 60 full time equivalent workers. It is found that product-marketing innovation has a high growth effect for skill-intensive firms below the median size. Organisational innovation also has a positive growth effect; however, this effect is not significantly different from zero. As in the baseline case, marketing innovation has a negative but insignificant growth effect. The flop side result, however, is found for larger firms in column 3. Here, we can see that organisational innovation constitutes an important growth driver for larger firms, whereas firms conducting product-marketing innovation do not gain as much from the activity. The latter finding indicates that the critique of the measure of product innovation may be valid. Interestingly, marketing innovation without product innovation has a positive and significant growth effect for larger firms. These results suggest that marketing and organisational changes have positive growth effects in larger organisations.

Next, we present an economy-wide estimate of the growth effect of innovation. To do this we use a weighted regression of the main specification, which is presented in column 4 . The estimates are weighted by establishment size and sample frequency from Statistics Denmark. The

\footnotetext{
${ }^{10}$ Similar results to those presented in this section is established for Table 3 , column 4 . The results are available upon request.
} 
regression shows that the growth effect in skill-intensive firms that conduct product-marketing innovation is positive and significant. This is the case even though large firms that tend to answer "yes" to engaging in product innovation as discussed above have larger weights. Skill-intensive firms conducting organisational innovation only also have a positive growth effect. Surprisingly, however, this effect is not significantly different from zero. When specifying the regression with organisational innovation as the only type of information included in the regression (not shown), we find that skill-intensive firms gain significantly from organisational innovation. Finally, skillintensive firms conducting marketing innovation but not product innovation have a positive but insignificant growth effect.

A concern regarding the results established above is that they may simply be a result of the selection of high growth firms into innovation. It may be the case that product-marketing innovation is introduced in firms that have higher productivity growth rates (see for example Caroli and Van Reenen (2001) and Ichniowski, Shaw, and Prennushi (1997)).

To deal with this potential selection problem, we include the lagged growth rates of real value added in the regressions as a robustness check. In other words, we include the annualised log change for the period 2002-2004. The issue is that high-growth firms potentially select themselves into innovation activities and low-growth firms do not. The lagged growth rates are instrumented with the initial real value added level measured in 2001, which follows Caroli and Van Reenen (2001). The main result established in this paper is unaffected by this specification. ${ }^{11}$

In this section, we have performed a number of robustness checks of the baseline specification of Table 4. Neither of these specifications change the main result that skill-intensive firms that perform product and marketing innovation experience a positive growth effect in the subsequent (long) period. We document that the combined innovation activity has an independent role in productivity growth and are able to disentangle the growth driver from organisational changes. On the contrary, product innovation or marketing innovation alone do not contribute to growth.

\footnotetext{
${ }^{11}$ Another check is to estimate the relationship between productivity growth and innovation activities using quantile regressions. The results have been estimated for the 0.50 quantile (the median), the 0.75 quantile, and the 0.25 quantile and can be obtained upon request to the authors. Similar results are found for all three regressions: The coefficients on product-marketing innovation are of similar magnitude independent of quantile. Moreover, it is found that the coefficient to product-marketing innovation is significantly larger than the coefficient to firms that perform organizational innovation only for the median firm as well as for the 0.75 quantile firm. This result is not established when estimating for the 0.25 quantile.
} 


\section{Discussion and conclusion}

The main result of this paper is that skill-intensive firms that engage in product and marketing innovation grow faster than skill-intensive firms that do not engage in these activities. Moreover, we find that firms that conduct product innovation but no marketing innovation or marketing innovation but no product innovation do not reap higher productivity growth.

An independent issue is to separate effects of product and marketing innovation from organisational innovation. In the applied data set, it turns out that the majority of firms that conduct product and marketing innovation also conduct organisational innovation. Therefore, we study whether firms that conduct product and/or marketing innovation gain positive growth effects in addition to those obtained through organisational innovation. Although the majority of innovative firms also engage in organisational innovation, we are able to rule out the concern that the estimated effect of product and marketing innovation is simply picking up growth effects generated through organisational innovation. Instead we find that product-marketing innovation and organisational innovation both play independent roles in productivity growth.

One important result of this analysis is that innovation activities generate higher productivity growth rates in skill-intensive firms, whereas they do not in unskilled-intensive firms. Indeed, innovation activities may result in negative growth rates in unskilled-intensive firms. Taking the estimated coefficients at face value, firms engaging in product and marketing innovation should have an education mix of employees with 16 or more years of education in relation to the total number of employees that exceeds the average value of the sample. A similar result is found for organisational innovation.

The broader implication of the positive growth effect in skill-intensive firms is twofold. The analysis finds that it may not always be appropriate to engage in innovation activities in unskilledintensive firms as the activity may not pay off. ${ }^{12}$ An important question in this respect is whether firms become more skill-intensive as they begin to engage in innovation, or whether the skill intensity to a high degree is fixed. If the latter is the case, it may be important to target skill-intensive firms with innovation-promoting policy programs. ${ }^{13}$ In this sense, the result of the analysis may have

\footnotetext{
${ }^{12}$ This idea has been suggested for the macro-perspective in Sørensen (1999). Here, the applied endogenous growth model predicts that skills are accumulated as the only growth-generating when human capital is below a threshold level, whereas both innovation activities and learning drive growth above this level. In steady-state equilibrium, growth is driven by innovation only.

${ }^{13}$ In the area of technological adoption a key determinant seems to be the skill-intensity of the plant. Adoption of new technology does not typically lead to a significant increase in the firm skill-intensity (see Doms, Dunne, and Troske (1997) and Caselli and Coleman (2001)).
} 
implications for industrial policy that is designed to increase innovation activities in firms. Instead of targeting all firms with programs designed to increase innovation, governments may instead direct the programs towards skill-intensive firms. Alternatively, governments should target human capital accumulation and innovation-promoting programs simultaneously. 


\section{References}

[1] Anderson, E., and D.C. Schmittlein, (1984), "Integration of the sales force: An empirical examination". RAND Journal of Economics 15 (3), 385-395.

[2] Athey, S., and S. Stern (1998). "An empirical framework for testing theories about complimentarity in organizational design". NBER Working Papers 6600, National Bureau of Economic Research

[3] Balsvik, R. (2011), "Is Labor Mobility a Channel for Spillovers from Multinationals? Evidence from Norwegian Manufacturing", Review of Economics and Statistics, 93(1), 285-297

[4] Bloom, N., R. Sadun and J. Van Reenen (2010), "Recent Advances in the Empirics of Organizational Economics", Annual Review of Economics, 2, 105-37

[5] Bloom, N., R. Sadun and J. Van Reenen (2012), "Americans do I.T. Better: US Multinationals and the Productivity Miracle", American Economic Review, 102(1), 167-201

[6] Bloom, N., and J. Van Reenen (2007), "Measuring and explaining management practices across firms and countries", The Quarterly Journal of Economics 122 (4), 1351-1408

[7] Bloom, N and J. Van Reenen (2010) "Why do Management Practices Differ across Firms and Countries?" Journal of Economic Perspectives, 24(1)

[8] Bresnahan, T. F., E. Brynjolfsson, and L.M. Hitt (2002), "Information technology, workplace organization, and the demand for skilled labor: Firm-level evidence", The Quarterly Journal of Economics 117 (1), 339-376.

[9] Caroli. E. and J. Van Reenen (2001). "Skill-biased Organizational Change? Evidence from a Panel of British and French Establishments", Quarterly Journal of Economics, 116(4), 14491492

[10] Caselli, F., and W. J. Coleman (2001), "Cross-Country Technology Diffusion: The Case of Computers", American Economic Review 91, 328-335

[11] Crespi, G., C. Criscuolo, and J. Haskel (2007), "Information technology, organizational change and productivity growth: evidence from UK firms", CEP Discussion Paper no. 783.

[12] Doms, M., T. Dunne, and K. Troske (1997), "Workers, Wages, and Technology", Quarterly Journal of Economics, 112, 253-290 
[13] Dutta, S., O. Narasimhan, and S. Rajiv (1999). "Success in High-Technology Markets: Is Marketing Capability Critical?" Marketing Science 18(4): 547-568.

[14] Gupta A. K, S.P. Raj and D. Wilemon (1986). "A Model for Studying R\&D-Marketing interfase in the product innovation process." Journal of Marketing Vol 50.

[15] Hall, B. H., J. Mairesse, and P. Mohnen (2010). Measuring the Returns to R\&D. In Hall, B. H. and N. Rosenberg, Handbook of the Economics of Innovation. Amsterdam and New York: Elsevier.

[16] Hall, B. H., (2011). Innovation and productivity. In: Productivity and Competitiveness, eds. J. Madsen and A. Sørensen. Nordic Economic Policy Review, 2, 167-204

[17] Griffith, R., S. Redding, and J. Van Reenen (2004). "Mapping the two Faces of R\&D: Productivity Growth in a Panel of OECD Industries." The Review of Economics and Statistics. 86(4), 883-895

[18] Ichniowski, C., K. Shaw, and G. Prennushi (1997), "The Effects of Human Resource Management Practices on Productivity: A Study of Steel Finishing Lines," American Economic Review

[19] Junge, M., B. Severgnini, and A. Sørensen (2012), "Evidence on the Impact of Education on Innovation and Productivity", CEBR working paper

[20] Milgrom, P., and J. Roberts (1990), "The economics of modern manufacturing, technology, strategy and organization", American Economic Review 80, 511-528.

[21] Mairesse, J., and P. Mohnen (2010), "Using Innovation Surveys for Econometric Analysis", in Handbook of The Economics of Innovation, B.H. Hall and N. Rosenberg (eds.), vol. 2

[22] Molina, D., and M-A Muendler (2010), "Preparing to Export", Working Paper

[23] OECD (2002). Frascati Manual: Proposed Standard Practice for Surveys On Research and Experimental Development. OECD, Paris.

[24] OECD (2005). Oslo Manual: Guidelines for Collecting and Interpreting Innovation Data. OECD, Paris.

[25] Park, S., (2004), "Quantitative analysis of network externalities in competing technologies: The VCR case", The Review of Economics and Statistics 86 (4), 937-945. 
[26] Sørensen, A. (1999), "R\&D, Learning, and Phases of Economic Growth", Journal of Economic Growth 4(4), 429-45, 1999 


\section{A Appendix: The general model}

In Section 3.3, two approaches are applied; one based on innovation types and another on firm types. In this appendix, we show that both of these approaches are consistent with a general version of the model presented in (3). In the following, we concentrate on the part of the model that is related to innovation; a part that we label $I N N O$ :

$$
I N N O=\lambda_{1} I^{P} E+\lambda_{2} I^{M} E+\lambda_{3} I^{P} I^{M} E+\lambda_{4} I^{O} E+\lambda_{5} I^{P} I^{O} E+\lambda_{6} I^{M} I^{O} E+\lambda_{7} I^{P} I^{M} I^{O} E
$$

Compared to (3), we have included additional interaction terms resulting in 3 extra parameters, $\lambda_{5}, \lambda_{6}$, and $\lambda_{7}$.

\section{A.1 Innovation types}

The model applied under the innovation types approach, i.e., equation (3), is obtained under the restriction that $\lambda_{5}=\lambda_{6}=\lambda_{7}=0$. This results in the following estimates $\hat{\lambda}_{1}, \hat{\lambda}_{2}, \hat{\lambda}_{3}$, and $\hat{\lambda}_{4}$ :

$$
I N N O=\hat{\lambda}_{1} I^{P} E+\hat{\lambda}_{2} I^{M} E+\hat{\lambda}_{3} I^{P} I^{M} E+\hat{\lambda}_{4} I^{O} E
$$

\section{A.2 Firm types}

Given the 3 innovation types, we can group innovative firms into seven different groups of firms after their the innovative activities that they perform:

$$
\begin{aligned}
& T_{1}=1 \text { if } I^{P}=1, I^{M}=1, I^{O}=1 ; T_{1}=0 \text { otherwise } \\
& T_{2}=1 \text { if } I^{P}=1, I^{M}=0, I^{O}=1 ; T_{2}=0 \text { otherwise } \\
& T_{3}=1 \text { if } I^{P}=0, I^{M}=1, I^{O}=1 ; T_{3}=0 \text { otherwise } \\
& T_{4}=1 \text { if } I^{P}=0, I^{M}=0, I^{O}=1 ; T_{4}=0 \text { otherwise } \\
& T_{5}=1 \text { if } I^{P}=1, I^{M}=1, I^{O}=0 ; T_{5}=0 \text { otherwise } \\
& T_{6}=1 \text { if } I^{P}=1, I^{M}=0, I^{O}=0 ; T_{6}=0 \text { otherwise } \\
& T_{7}=1 \text { if } I^{P}=0, I^{M}=1, I^{O}=0 ; T_{7}=0 \text { otherwise }
\end{aligned}
$$

Using these 7 types of innovative firms, the general version of $I N N O$ is rewritten to:

$$
I N N O=\psi_{1} T_{1} E+\psi_{2} T_{2} E+\psi_{3} T_{3} E+\psi_{4} T_{4} E+\psi_{5} T_{5} E+\psi_{6} T_{6} E+\psi_{7} T_{7} E
$$


with

$$
\begin{aligned}
& \psi_{1}=\lambda_{1}+\lambda_{2}+\lambda_{3}+\lambda_{4}+\lambda_{5}+\lambda_{6}+\lambda_{7} \\
& \psi_{2}=\lambda_{1}+\lambda_{4}+\lambda_{5} \\
& \psi_{3}=\lambda_{2}+\lambda_{4}+\lambda_{6} \\
& \psi_{4}=\lambda_{4} \\
& \psi_{5}=\lambda_{1}+\lambda_{2}+\lambda_{3} \\
& \psi_{6}=\lambda_{1} \\
& \psi_{7}=\lambda_{2}
\end{aligned}
$$

The firm type approach is consistent with the innovation type approach when the restrictions $\lambda_{5}=0, \lambda_{6}=0$, and $\lambda_{7}=0$ are implemented. In this case, $\psi_{1}=\lambda_{1}+\lambda_{2}+\lambda_{3}+\lambda_{4}, \psi_{2}=\lambda_{1}+\lambda_{4}$, $\psi_{3}=\lambda_{2}+\lambda_{4}$, and $\psi_{4}=\lambda_{4}, \psi_{5}=\lambda_{1}+\lambda_{2}+\lambda_{3}, \psi_{6}=\lambda_{1}$, and $\psi_{7}=\lambda_{2}$.

In order to avoid using 7 different firm types in the main text, the baseline regression in Section 3.3. is not based on these restriction. Instead we base the analysis reported in the main text on 4 firm types with innovation activities. The model applied under the firm types approach is obtained under the following restrictions.

- Firm types 1 in the main text is defined as firms with product-marketing innovation. These firms are identified for $T_{1}=1$ or $T_{5}=1$. These firm types are assumed to have similar growth effects, implying that: $\psi_{1,5}=\psi_{1}=\psi_{5}$ or $\lambda_{4}+\lambda_{5}+\lambda_{6}+\lambda_{7}=0$

- Firm type 2 in the main text is defined as firms with product innovation but no marketing innovation. These firms are identified for $T_{2}=1$ or $T_{6}=1$. These firm types are assumed to have similar growth effects, implying that: $\psi_{2,6}=\psi_{2}=\psi_{6}$ or $\lambda_{4}+\lambda_{5}=0$.

- Firm type 3 in the main text is defined as firms with marketing innovation but no product innovation. These firms are identified for $T_{3}=1$ or $T_{7}=1$. These firm types are assumed to have similar growth effects, implying that: $\psi_{3,7}=\psi_{3}=\psi_{7}$ or $\lambda_{4}+\lambda_{6}=0$.

- Firm type 4 in the main text is defined as firms with organisational innovation but no product innovation or marketing innovation. There is no restrictions for the relevant parameter $\psi_{4}$.

Thereby, we allow firms in the first group of firms and firms in the fifth group of firms to have similar effects on productivity growth, even though firms in the former group have organisational 
innovation in addition to product-marketing innovation. This is also the case for firms with product innovation but no marketing innovation and for firms with marketing innovation but no product innovation. This is of course inconsistent with the applied theoretical model, since we ignore that firms belonging to the first three groups of firms have organisational innovation in addition to product and/or marketing innovaton.

Implementing the restrictions described in the bullits above imply that $I N N O$ can berewritten to

$$
I N N O=\hat{\phi}_{1,5}\left(T_{1}+T_{5}\right) E+\hat{\phi}_{2,6}\left(T_{2}+T_{6}\right) E+\hat{\phi}_{3,7}\left(T_{3}+T_{7}\right) E+\hat{\phi}_{4} T_{4} E
$$

It is clear that the two approaches lead to different estimates, i.e., $\hat{\phi}_{1,5} \neq \hat{\lambda}_{1}$ etc. In other words, the two approaches origin from the same general model, but are not nested. Under the firm type approach, the constraints imply that $\lambda_{4}=-\lambda_{5}=-\lambda_{6}=\lambda_{7}$. In this sense, other complementarities than the complementarity between product and marketing is enforced by the constraints. The two approaches, however, lead to identical estimates under the restriction that $\psi_{4}=\lambda_{4}=0$, which is evident from Table 2, column 4, and Table 4, column 1, that present identical results. Moreover, the two approaches lead to identical results if all innovative firms with innovation activities perform organisational innovation. Results for this case is reported in Table 4, column 4.

As mentioned, we do not present estimation results for the 7 groups of firms. The qualitative results for this case, however, are similar to those presented in Table 4 , implying that $\lambda_{5} \neq 0, \lambda_{6} \neq 0$, and $\lambda_{7} \neq 0$ do not have important implications for the results. When testing these contraints for the firm type approach simultaneously, the F-test has a critical p-value of 0.55 implying that the restrictions cannot be rejected. These results are available upon request. 
Figure 1: Timing of variables in regressions.

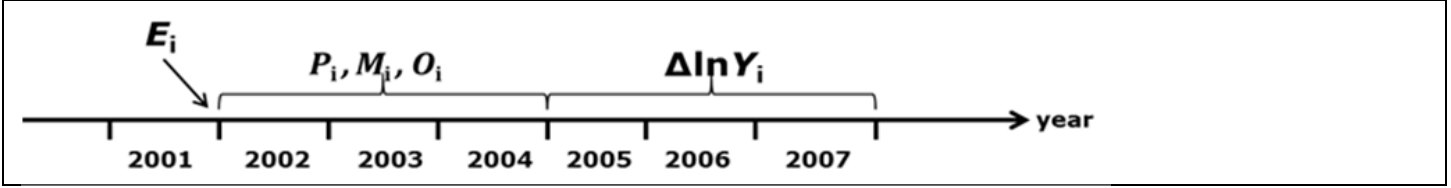

Figure 2: Labor Productivity Growth, 2005-2007. (Deviation from average growth rate in skill-intensive firms from mean). Groups of Firms Divided after types of Innovation Activities.

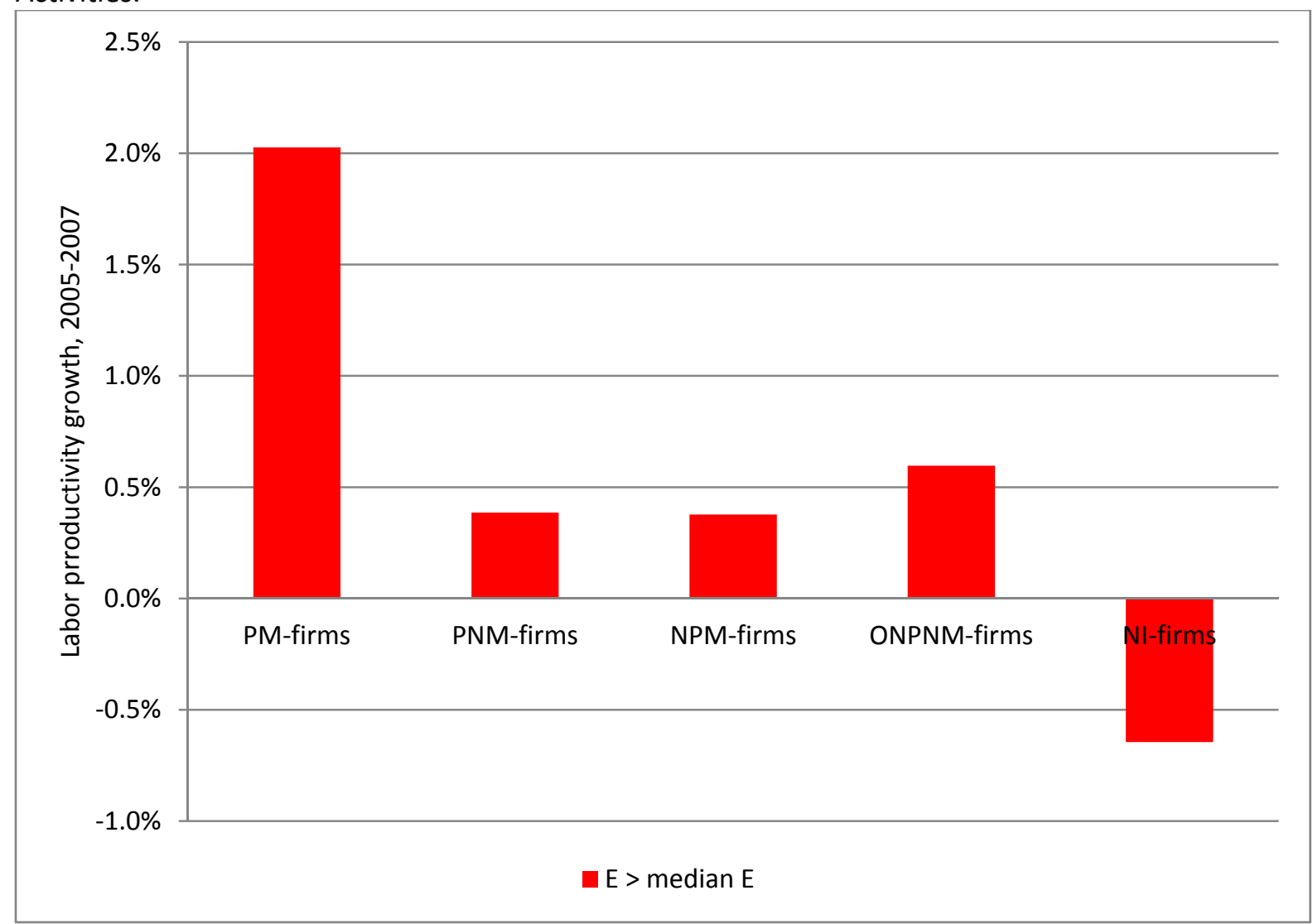

Note: Firms are considered to be skill-intensive if their education share in 2001 exceeds the median share within their firm type 
Table 1A: Firms with Different Types of Innovation

\begin{tabular}{|c|c|c|c|c|}
\hline & \multicolumn{2}{|c|}{ Product Innovation } & \multirow[b]{2}{*}{ Total } \\
\hline & & Yes & No & \\
\hline Marketing & Yes & 164 & 105 & 269 \\
\hline \multirow[t]{2}{*}{ Innovation } & No & 363 & 689 & 1,052 \\
\hline & Total & 527 & 794 & 1,321 \\
\hline
\end{tabular}

Table 1B: Firms with Different Types of Innovation

\begin{tabular}{|c|c|c|c|c|c|}
\hline $\begin{array}{c}\text { Organisation } \\
\text { Innovation }\end{array}$ & & \multicolumn{2}{|c|}{ Product Innovation } & Total \\
\hline & Marketing & Yes & 136 & 68 & 204 \\
\hline & Innovation & No & 265 & 307 & 572 \\
\hline & & Total & 401 & 375 & 776 \\
\hline
\end{tabular}

\begin{tabular}{|c|c|c|c|}
\hline $\begin{array}{l}\text { No organisation } \\
\text { Innovation }\end{array}$ & & $\begin{array}{l}\text { Product Innovation } \\
\text { Yes No }\end{array}$ & Total \\
\hline & $\begin{array}{l}\text { Marketing Yes } \\
\text { Innovation No }\end{array}$ & $\begin{array}{lc}28 & 37 \\
98 & 382\end{array}$ & $\begin{array}{r}65 \\
480\end{array}$ \\
\hline & Total & 419 & 545 \\
\hline
\end{tabular}


Table 2: Firm Level Productivity Functions. Product and Marketing. Change in In(Value added 2004-2007) (annualized mean $=.024$ )

\begin{tabular}{|c|c|c|c|c|c|c|c|c|c|c|c|c|}
\hline & \multicolumn{2}{|l|}{1} & \multicolumn{2}{|l|}{2} & \multicolumn{2}{|l|}{3} & \multicolumn{2}{|l|}{4} & \multicolumn{2}{|l|}{5} & \multicolumn{2}{|l|}{6} \\
\hline \multirow{2}{*}{ dlnL } & 0.840 & 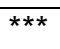 & 0.837 & 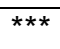 & 0.840 & $\star \star \star$ & 0.842 & $\star \star \star$ & 0.840 & 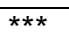 & 0.839 & $\star \star \star \star$ \\
\hline & 0.035 & & 0.035 & & 0.035 & & 0.035 & & 0.035 & & 0.035 & \\
\hline \multirow[t]{2}{*}{ dlnK } & 0.027 & $\star \star$ & 0.026 & * & 0.027 & $\star \star$ & 0.028 & $\star \star$ & 0.028 & $\star \star$ & 0.027 & $\star \star$ \\
\hline & 0.014 & & 0.014 & & 0.014 & & 0.014 & & 0.014 & & 0.014 & \\
\hline \multirow[t]{2}{*}{$P * M$} & & & & & & & -0.014 & & -0.001 & & -0.004 & \\
\hline & & & & & & & 0.022 & & 0.012 & & 0.010 & \\
\hline \multirow[t]{2}{*}{$P$} & -0.004 & & & & -0.006 & & -0.003 & & -0.004 & & & \\
\hline & 0.008 & & & & 0.009 & & -0.010 & & 0.010 & & & \\
\hline \multirow[t]{2}{*}{$\mathrm{M}$} & & & 0.007 & & 0.008 & & 0.013 & & & & & \\
\hline & & & 0.009 & & 0.010 & & 0.018 & & & & & \\
\hline \multirow[t]{2}{*}{$P * M * E$} & & & & & & & 0.206 & & 0.086 & & 0.127 & $\star \star \star$ \\
\hline & & & & & & & 0.168 & & 0.059 & & 0.046 & \\
\hline \multirow[t]{2}{*}{$P * E$} & 0.087 & $\star \star$ & & & 0.088 & * & 0.045 & & 0.059 & & & \\
\hline & 0.044 & & & & 0.053 & & 0.052 & & 0.054 & & & \\
\hline \multirow[t]{2}{*}{$M * E$} & & & 0.019 & & -0.007 & & -0.120 & & & & & \\
\hline & & & 0.069 & & 0.076 & & 0.157 & & & & & \\
\hline \multirow[t]{3}{*}{$E$} & 0.001 & & 0.031 & & 0.003 & & 0.018 & & 0.002 & & 0.020 & \\
\hline & 0.036 & & 0.030 & & 0.034 & & 0.032 & & 0.036 & & 0.032 & \\
\hline & & & & & & & $(P+M+P * M)^{\star} E$ & $E=0$ & $(P+P * M)^{\star}$ & $\mathrm{E}=0$ & & \\
\hline F-test & & & & & & & 7.87 & 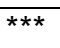 & 8.90 & & & \\
\hline R2 & 0.491 & & 0.489 & & 0.491 & & 0.493 & & 0.491 & & 0.491 & \\
\hline $\mathrm{N}$ & 1321 & & 1321 & & 1321 & & 1321 & & 1321 & & 1321 & \\
\hline
\end{tabular}

Standard errors are in parentheses. These are long-differenced specifications. Value added, capital, and labor are annualized changes 2004-2007. Marketing innovation (M), product innovation (P), and organizational innovation (O). All regressions include industry dummies, regional dummies, ownership dummies, and export intensity. 
Table 3: Firm Level Productivity Functions. Product, Marketing, and Organizational Innovation. Change in In(Value added 2004-2007) (annualized mean $=.024$ )

\begin{tabular}{|c|c|c|c|c|c|c|c|c|}
\hline & 1 & & 2 & & 3 & & 4 & \\
\hline \multirow[t]{2}{*}{$\mathrm{dlnL}$} & 0.837 & 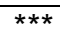 & 0.841 & $\star \star \star \star ~$ & 0.839 & 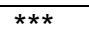 & 0.838 & 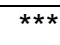 \\
\hline & 0.035 & & 0.035 & & 0.035 & & 0.035 & \\
\hline \multirow[t]{2}{*}{ dlnK } & 0.028 & ** & 0.029 & ** & 0.029 & ** & 0.029 & ** \\
\hline & 0.014 & & 0.014 & & 0.014 & & 0.014 & \\
\hline \multirow{3}{*}{$P * M$} & & & & & & & & \\
\hline & & & -0.014 & & -0.001 & & -0.004 & \\
\hline & & & 0.022 & & 0.012 & & 0.010 & \\
\hline \multirow[t]{2}{*}{$\mathrm{P}$} & & & -0.003 & & -0.005 & & & \\
\hline & & & 0.010 & & 0.010 & & & \\
\hline \multirow[t]{2}{*}{$\mathrm{M}$} & & & 0.014 & & & & & \\
\hline & & & 0.018 & & & & & \\
\hline \multirow[t]{2}{*}{$\mathrm{O}$} & 0.000 & & -0.001 & & 0.001 & & 0.000 & \\
\hline & 0.008 & & 0.009 & & 0.008 & & 0.008 & \\
\hline \multirow{2}{*}{$\mathrm{P}^{*} \mathrm{M}^{\star} \mathrm{E}$} & & & 0.196 & & 0.077 & & 0100 & ** \\
\hline & & & 0.163 & & 0.061 & & 0.049 & \\
\hline \multirow[t]{2}{*}{$P^{*} E$} & & & 0.022 & & 0.036 & & & \\
\hline & & & 0.059 & & 0.059 & & & \\
\hline \multirow[t]{2}{*}{$M^{*} E$} & & & -0.119 & & & & & \\
\hline & & & 0.153 & & & & & \\
\hline \multirow[t]{2}{*}{$\mathrm{O}^{*} \mathrm{E}$} & 0.100 & ** & 0.079 & & 0.079 & & 0.086 & * \\
\hline & 0.049 & & 0.052 & & 0.053 & & 0.050 & \\
\hline \multirow[t]{2}{*}{$\mathrm{E}$} & -0.024 & & -0.018 & & -0.033 & & -0.027 & \\
\hline & 0.048 & & 0.040 & & 0.047 & & 0.048 & \\
\hline & & & & & & & & \\
\hline \multirow{2}{*}{ F-test } & & & $(P+M+P * M) * B$ & $E=0$ & $(P+P * M)$ & ${ }^{*} \mathrm{~F}=0$ & & \\
\hline & & & 3.32 & * & 4.53 & ** & & \\
\hline & & & & & & & & \\
\hline R2 & 0.491 & & 0.495 & & 0.493 & & 0.493 & \\
\hline $\mathrm{N}$ & 1321 & & 1321 & & 1321 & & 1321 & \\
\hline
\end{tabular}

Standard errors are in parentheses. These are long-differenced specifications Value added, capital, and labor are annualized changes 2004-2007. Product innovation $(P)$, marketing innovation $(M)$, and organizational innovation $(\mathrm{O})$. All regressions include industry dummies, regional dummies, ownership dummies, and export intensity.. 
Table 4: Firm Level Productivity Functions. Product, Marketing, and Organizational Innovation. Change in In(Value added 2004-2007) (annualized mean $=.024$ )

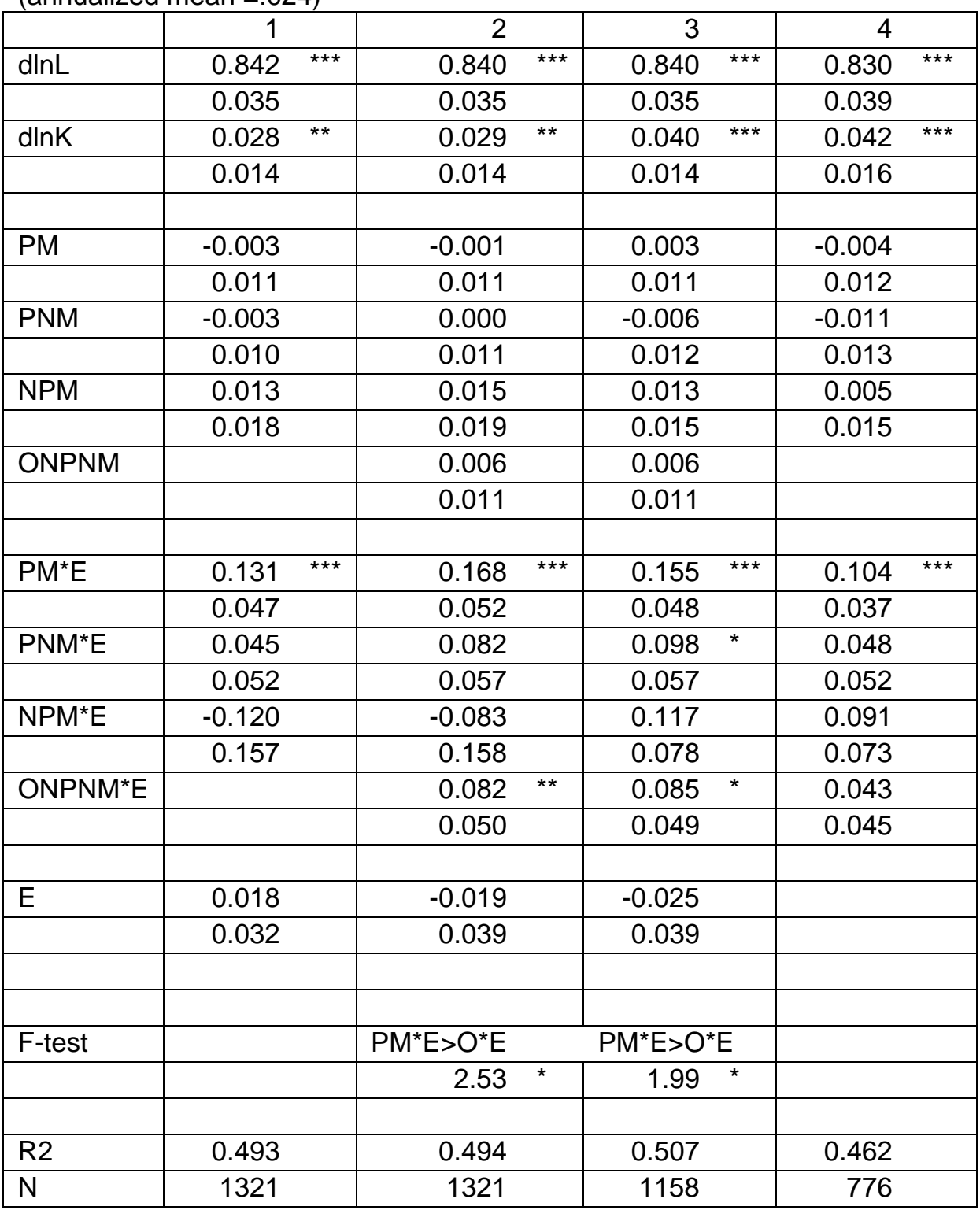

Standard errors are in parentheses. These are long-differenced specifications. Value added, capital, and labour are annualized changes 2004-2007. Firms performing: product-marketing innovation (PM), product innovation but no marketing innovation (PNM), marketing innovation but no product innovation (NPM), organizational innovation but no product or marketing innovation (ONPNM). All regressions include industry dummies, regional dummies, ownership dummies, and export intensity. 
Table 5: Firm Level Productivity Functions. Product, Marketing, and Organizational Innovation. Change in In(Value added 2004-2007) (annualized mean =.024)

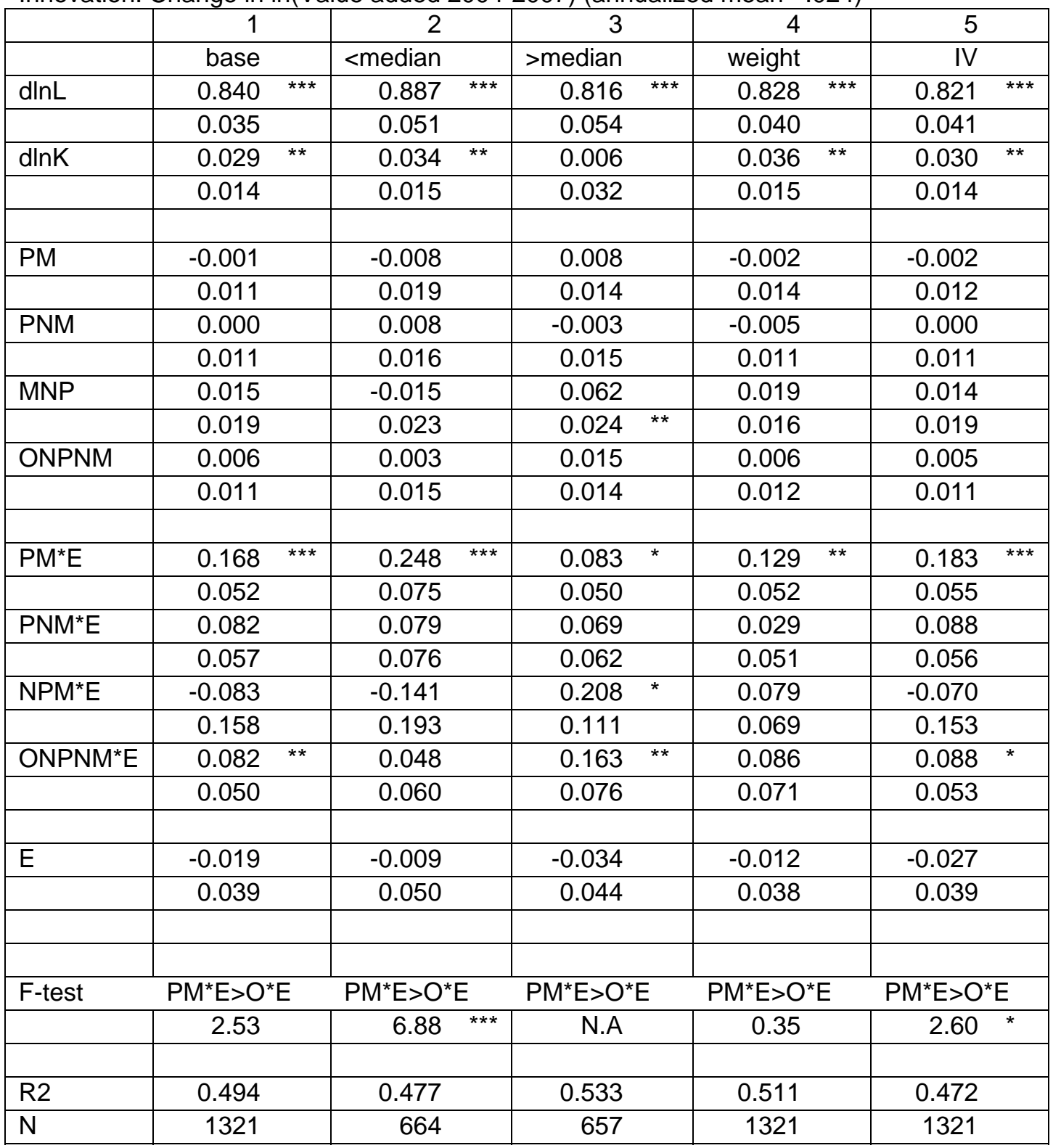

Standard errors are in parentheses. These are long-differenced specifications. Value added, capital, and labour are annualized changes 2004-2007. Firms performing: productmarketing innovation (PM), product innovation but no marketing innovation (PNM), marketing innovation but no product innovation (NPM), organizational innovation but no product-marketing innovation (ONPNM). All regressions include industry dummies, regional dummies, ownership dummies, and export intensity. 
Appendix Table 1: Descriptive Statistics of sample

\begin{tabular}{|c|c|c|c|c|c|}
\hline Variable & Obs & Mean & Std. Dev & Min & Max \\
\hline dln(value added) & 1321 & 0.024074 & 0.189312 & -1.21353 & 1.187493 \\
\hline dln(value added) -dln(FTE) & 1321 & 0.011242 & & & \\
\hline $\ln ($ value added) 2001 & 1321 & 17.07981 & 1.57534 & 10.49904 & 22.89043 \\
\hline $\ln ($ value added) 2004 & 1321 & 17.21692 & 1.516969 & 12.76903 & 22.92691 \\
\hline product innovation & 1321 & 0.39894 & & 0 & 1 \\
\hline product-marketing innovation & 1321 & 0.124148 & & 0 & 1 \\
\hline product innovation, no marketing innovation & 1321 & 0.274792 & & 0 & 1 \\
\hline organizational innovation only & 1321 & 0.283876 & & 0 & 1 \\
\hline $\mathrm{E}_{2001}$ & 1321 & 0.166255 & 0.209093 & 0 & 1 \\
\hline Export intensity & 1321 & 0.260733 & 0.336472 & 0 & 1 \\
\hline dln(capital) & 1321 & 0.006381 & 0.379923 & -1.95769 & 2.346803 \\
\hline $\mathrm{D} \ln (\mathrm{FTE})$ & 1321 & 0.012832 & 0.152181 & -1.25579 & 1.116635 \\
\hline labor input (FTE) & 1321 & 195.7033 & 513.3778 & 0 & 10047 \\
\hline labor input (heads) & 1321 & 194.0999 & 479.6713 & 1 & 9838 \\
\hline Firms in primary sector & 1321 & 0.003028 & & 0 & 1 \\
\hline Firms in manufacturing & 1321 & 0.436033 & & 0 & 1 \\
\hline Firms in construction & 1321 & 0.050719 & & 0 & 1 \\
\hline Firms in retail and wholesale trade & 1321 & 0.245269 & & 0 & 1 \\
\hline Firms in transportation & 1321 & 0.031794 & & 0 & 1 \\
\hline Firms in communication & 1321 & 0.009841 & & 0 & 1 \\
\hline Firms in FIRE & 1321 & 0.219531 & & 0 & 1 \\
\hline region1 & 1321 & 0.024981 & & 0 & 1 \\
\hline region2 & 1321 & 0.097653 & & 0 & 1 \\
\hline region3 & 1321 & 0.120363 & & 0 & 1 \\
\hline region4 & 1321 & 0.043906 & & 0 & 1 \\
\hline Ownership 1 & 1321 & 0.870553 & & 0 & 1 \\
\hline Ownership 2 & 1321 & 0.11355 & & 0 & 1 \\
\hline Ownership 3 & 1321 & 0.015897 & & 0 & 1 \\
\hline
\end{tabular}

